\section{JURNAL ABDIMAS

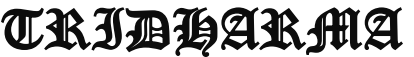

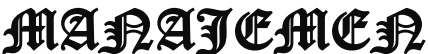

\title{
PENGENALAN KEPEMIMPINAN DAN ETIKA BERORGANISASI PADA REMAJA KARANG TARUNA KELURAHAN PONDOK BENDA KECAMATAN PAMULANG KOTA TANGERANG SELATAN
}

\author{
Styo Budi Utomo, Derita Qurbani,Hendri Prasetyo, \\ Muhammad Arief,Ugeng Budi Purwoko \\ Dosen Ekonomi Fakultas Ekonomi Universitas Pamulang \\ Email : dosen01759@unpam.ac.id,dosen00806@unpam.ac.id,dosen02304@unpam.ac.id
}

\begin{abstract}
ABSTRAK
Pengabdian Kepada Masyarakat (PKM) ini bertujuan untuk memberikan pengetahuan kepada Karang Taruna Kel. Pondok Benda Kota Tangerang Selatan tentang bagaimana mengelola dan mengembangkan organisasi. Selain itu memberikan pengetahuan akan pentingnya mengelola oragnisasi dan sumber daya manusia di dalam berorganisasi.

Sasaran kegiatan PKM adalah pemuda Karang Taruna Kel. Pondok Benda Kec. Pamulang. Permasalahan diselesaikan melalui tiga (3) tahapan yaitu: persiapan, pelaksanaan dan evaluasi. Dalam kegiatan ini dilakukan dengan cara memberikan penyuluhan dengan materi sesuai kebutuhan dalam berorganisasi.

Hasil kegiatan berjalan sesuai dengan yang diharapkan. Hal ini terlihat dari antusias para peserta. Para peserta memeroleh input dari materi-materi yang disampaikan yang meliputi materi Manajemen Sumber Daya Manusia (MSDM) dan Organisasi. Kegiatan juga mendapat dukungan penuh dari para civitas kelurahan. Kegiatan ini dinilai menambah khazanah keilmuan bagi para pemuda Karang Taruna.
\end{abstract}

\section{Kata Kunci : Manajemen Sumber Daya Manusia, Organisasi}

\begin{abstract}
ABSTRAC
This Community Service (PKM) aims to provide knowledge to Karang Taruna Kel. Pondok Benda Kota Tangerang Selatan about how to manage and develop an organization. In addition, it provides knowledge on the importance of managing organizations and human resources in organizations.

The target of PKM activities is youth from the Youth Organization, Kel. Pondok Benda Kec. Pamulang. The problem is resolved through three (3) stages, namely: preparation, implementation and evaluation. In this activity carried out by providing counseling with material according to organizational needs.

The results of the activity went as expected. This can be seen from the enthusiasm of the participants. The participants received input from the materials presented which included Human Resource Management (HRM) and Organization. The activity also received full
\end{abstract}




\section{JURNAL ABDIMAS

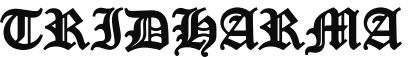

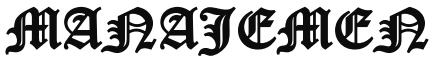

P-ISSN 2715-7105, E-ISSN 2716-070X

Jurnal ABDIMAS Vol. 2, No. 1, Januari 2021,Hal (35-43)

@ Prodi Manajemen Fakultas Ekonomi Universitas Pamulang

Email: abdimasjurnal.unpam@ gmail.com Telp: (021) 741-2566

support from the urban village community. This activity is considered to add to the scientific treasure of the youth of the Youth Organization.

\section{Keywords: Human Resource Management, Organization}

\section{PENDAHULUAN}

Dewasa ini sudah banyak bermunculan organisasi - organisasi di Indonesia. Dengan semakin banyaknya organisasi yang muncul, diharapkan dapat memberikan sebuah karakter tersendiri pada masyarakat tanpa memandang siapa yang menciptakan organisasi tersebut. Merebaknya organisasi yang bermunculan dikahawtirkan akan menimbulkan dampak kepada sosial dan lingkungan sekitar. apad akhir-akhir ini banyak yang mengatasnamakan organisasi masyarakat untukmendapat uang dnegan cara menjual nama organisasi tersbut. oleh karena itu perlu adanya pengenalan berorgaisasi yang benar dan mengelola organisasi tersbut. diharapkan dalam setiaprganisasi akan mampu memabawa tujuan dari masingmasing organisasi.

Salah satu organisasi yang muncul dan terus berkembang hampir disetiap keluarahan ialah organisasi kepemudaan atau karang taruna. Karang Taruna adalah organisasi sosial wadah pengembangan generasi muda yang tumbuh dan berkembang berdasarkan kesadaran dan tanggungjawab sosial dari, oleh dan untuk masyarakat terutama generasi muda di wilayah desa / kelurahan. dengan melalui pemahaman tentang kepemimpinan dan megelola organisasi dengan benar diharapakan para pemuda generasi penerus mampu mewujudkan tujuan dari pada organiasi yang dipimpinnya.

Organisasi kepemudaan seperti karang taruna, terutama bagi pemula ikut dalamorganisasi ini harus mengetahui dan memahami tentang suatu organisasi baik organisasi social maupun organisasi yang mneghasilkan profit (perusahaan). Tetapi, pada kesempatan ini menekankan pada sisi kepemimpinan agar kelak bagi peimpinan karang taruna dan atau pemuda karang taruna umumnya agar lebih memahami tentang sikap kepemimpinan dan bagaimana beretika dalam suatu organisasi yang benar.

Tanpa mengesampingkan yang lain, kepemimpinan menjadi titik penting bagi keberhasilan dan kesuksesan suatu organisasi. Seorang pemimpin suatu organisasi yang bijaksana dan baik harus dapat memberikan kepuasan kepada para anggotanya dan selalu berusaha memperhatikan gairah dan semangat mereka. Oleh karena hal tersebut pemimpin harus mempunyai kemampuan dalam mengelola, mengarahkan, mempengaruhi, memerintah dan memotivasi anggota organisasi untuk mencapai tujuan yang diinginkan. Didalam memimpin organisasi seperti karang taruna dimana tidak ada istilah gaji, honor ataupun bonus, maka pimpinan harus mampu menjalin komunikasi kepada seluruh anggota agar mampu menciptakan suasana keakraban didalam organisasi. Baiknya pemimpin berkomunikasi dengan anggotanya dapat meningkatkan rasa motivasi anggota untuk melakukan yang terbaik bagi organisasinya.

Dalam keadaan ini, timbul pertanyaan mengenai kepemimpinan yang bagaimana yang cocok dan mampu membawa organisasi menghadapi tantangan yang ada. Sehubungan dengan hal tersebut, penulis berupaya memberikan jalan keluar yang berlandaskan pada teori dan konsep kepemimpinan yang dapat membawa organisasi mengatasi tantangan yang akan dibahas dan diharapkan dapat mewujudkan tujuan dari organisasi.

\section{RUMUSAN MASALAH}

Dengan mempertimbangkan latar belakang yang telah diutarakan diatas dapat kami rumuskan : 


\section{JURNAL ABDIMAS

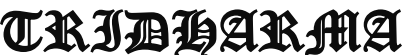 \\ AIA}

1. Bagiamana kita menambah wawasan tentang organisasi kepada karang taruna Kel. Pondok Benda?

2. Bagiamana kita memunculkan sikap berorganisasi non profit

3. Bagiamana cara menambah nilai organisasi terhadap masyarakat sekitar kel. Pondok Benda?

\section{TUJUAN PELAKSANAAN}

Dengan adanya kegiatan penyuluhan tersebut diharapkan Karang Taruna Kel.Pondok Benda mampu mengelola organisasi, mempunyai budaya yang baik serta menambah nilai positif pada lingkungan seiktar Kel. Pondok Benda.

\section{TINJAUAN PUSTAKA}

1. Pengertian Manajemen Sumber Daya Manusia

Manajemen sumber daya manusia merupakan bagian dari ilmu manajemen, yang berarti merupakan suatu usaha untuk mengarahkan dan mengelola sumber daya manusia di dalam suatu organisasi agar mampu berfikir dan bertindak sebagaimana yang diharapkan organisasi. Organisasi yang maju tentu dihasilkan oleh karyawan yang dapat mengelola organisasi tersebut ke arah kemajuan yang diinginkan organisasi, sebaliknya tidak sedikit organisasi yang hancur dan gagal karena ketidak mampuannya dalam mengelola sumber daya manusia.

Manajemen Sumber Daya Manusia menurut beberapa ahli Diantaranya Menurut Sunyoto (2012:1) "Manajemen Sumber Daya Manusia merupakan salah satu faktor penting dalam suatu organisasi selain faktor aktivas dan modal. Sebagai salah satu fungsi penting maka manajemen sumber daya manusia harus dikelola dengan baik untuk meningkatkan efisiensi dan efektivitas organisasi.

Lalu Menurut Hasibuan, Malayu S. P (2017:10) menyatakan bahwa "Manajemen sumber daya manusia adalah ilmu dan seni mengatur hubungan dan peranan tenaga kerja agar efektif dan efisien membantu terwujudnya tujuan perusahaan, karyawan dan masyarakat". Sedangkan menurut Handoko, Hani. T (2012:4) "Manajemen sumber daya manusia adalah proses penarikan, seleksi, pengembangan, pemeliharaan dan penggunaan sumber daya manusia untuk mencapai tujuan individu maupun organisasi".

Dari beberapa pengertian Sumber Daya Manusia di atas, maka dapat disimpulkan bahwa Manajemen Sumber Daya Manusia adalah rancangan sistem-sistem formal dalam sebuah organisasi untuk memastikan penggunaan bakat manusia secara efektif dan efisien yang mengatur hubungan dan peranan tenaga kerja, pengorganisasian, pengkoordinasian, pelaksanaan, dan pengawasan terhadap pengadaan, pengembangan, pemberian balas jasa, pengintegrasian, pemeliharaan, dan pemisahan tenaga kerja dalam rangka mencapai tujuan organisasi.

\section{Sumber-Sumber Manajemen}

Sumber-sumber manajemen menurut Nugroho (2014:4-5) adalah sebagai berikut:

1. Men atau manusia. Merupakan sarana penting dari setiap manajer untuk mencapai tujuan yang telah ditentukan terlebih dahulu. Berbagai macam aktivitas itu dapat dilihat dari proses, seperti: planning, organizing, staffing, directing, dan controlling.

2.Money atau uang. Untuk melakukan berbagai aktivitas diperlukan uang, seperti gaji, membeli peralatan- 


\section{JURNAL ABDIMAS

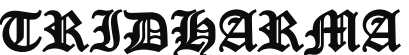 AtA}

peralatan, biaya perawatan, dan lainlain. Kegagalan atau ketidak lancaran manajemen banyak dipengaruhi perhitungan atau ketelitian dalam penggunaan uang.

3.Material atau bahan-bahan. Dalam proses pelaksanaan kegiatan manusia menggunakan material atau bahanbahan, karena dianggap atau sarana manajemen untuk mencapai tujuan.

4. Machines atau mesin. Dalam kemajuan teknologi sekarang ini manusia bukan lagi sebagai pembantu bagi mesin seperti pada masa sebelum revolusi industri, namun sebaliknya mesin berubah kedudukannya sebagai pembantu manusia.

5. Methods atau metode. Untuk melakukan kegiatan-kegiatan secara berdaya guna, manusia dihadapkan pada berbagai alternatif metode atau cara melakukan pekerjaan.

6. Market atau pasar. Pasar merupakan sasaran manajemen yang penting, karena merupakan tujuan proses aktivitas manajemen.

\section{Fungsi-Fungsi Manajemen}

Menurut Robbins dan Coulter (2015:9), mendefinisikan "Fungsi manajemen meliputi perencanaan (planning), pengorganisasian (organizing), pengarahan (actuating) dan pengendalian (controlling). Pendapat serupa dikemukakan oleh Safroni (2016:47) berpendapat "Fungsi-fungsi manajemen meliputi perencanaan, pengorganisasian, pengarahan, pengkoordinasian, pengendalian". Dari perbandingan beberapa fungsi-fungsi manajemen di atas, dapat dipahami bahwa semua manajemen diawali dengan perencanaan (planning) karena perencanaan yang akan menentukan tindakan apa yang harus dilakukan selanjutnya. Setelah perencanaan adalah pengorganisasian (organizing). Hampir semua ahli menempatkan pengorganisasian diposisi kedua setelah perencanaan.
Adapun secara umum penjelasan mengenai fungsi-fungsi manajemen dikemukakan Suherman (2014:12) sebagai berikut :

a. Perencanaan

Perencanaan merupakan suatu cara yang sistematis untuk menjalankan suatu pekerjaan. Perencanaan memiliki hubungan yang sangat erat dengan pengambilan keputusan

b. Pengorganisasian

Setelah para manajer menetapkan tujuan dan menyusun rencana atau program untuk mencapainya, maka perlu merancang dan mengembangkan organisasi agar dapat berjalan dengan baik.

$\begin{array}{ll}\text { c. } & \begin{array}{l}\text { Penyusunan } \\ \text { (Staffing) }\end{array} \\ \text { Penyusunan } & \text { personalia }\end{array}$ diperlukan untuk menyelesaikan tugas setelah disusun struktur pekerjaan, dipahami bidang-bidang pekerjaan yang akan dilakukan dan penempatan tenaga-tenaga yang sesuai.

\section{d. Pengarahan (Directing) \\ Perencanaan,} pengorganisasian dan penyusunan pegawai harus dijalankan, tetapi harus ada pihak yang memastikan seluruh sumber daya memang mengerjakan pekerjaan untuk mencapai tujuan organisasi. Oleh karena itu, perlu adanya pengarahan (directing)

\section{e. Pengendalian (Controlling) \\ Diantara beberapa fungsi} manajemen, pengendalian memiliki peran yang sangat penting. Pengendalian berfungsi untuk mengevaluasi apakah tujuan dapat dicapai, dan apabila tidak dapat dicapai dicari faktor penyebabnya, 


\section{JURNAL ABDIMAS

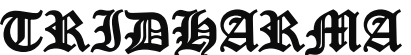 \\ AlA}

sehingga dapat dilakukan tindakan perbaikan.

Berdasarkan beberapa pendapat di atas, maka penulis menyimpulkan bahwa fungsi manajemen adalah pemutakhiran perencanaan, pengorganisasian, pengarahan, pengkoordinasian, pengendalian untuk melakukan proses pemasaran.

\section{Pengertian Organisasi}

Organisasi merupakan suatu sistem yang terdiri dari sub-sistem atau bagian-bagian yang saling berkaitan satu sama lainnya dalam melakukan aktivitasnya. Aktivitas ini bukanlah merupakan suatu kegiatan yang temporer atau sesaat saja, akan tetapi merupakan kegiatan yang memiliki pola atau urut-urutan.

Organisasi sering diartikan sebagai kelompok yang secara bersama-sama ingin mencapai suatu tujuan yang sama. Handoko (2000:6) mendifinisikan organisasi sebagai suatu proses perencanaan yang meliputi penyusunan, pengembangan dan pemeliharaan suatu struktur atau pola hubungan-hubungan kerja dari orang-orang dalam suatu kelompok kerja.

Anthony (995:1) menjelaskan bahwa organisasi merupakan suatu kelompok manusia yang berinteraksi melakukan berbagai kegiatan secara koordinasi untuk mencapai tujuan, dimana pada dasarnya bahwa individu tidak dapat mencapai tujuan secara sendiri-sendiri. Artinya tujuan organisasi dapat dicapai melalui tatanan/manajemen yang dilakukan terhadap sejumlah orang sebagai pelaksana pekerjaan pekerjaan organisasi.

Organisasi memperoleh sumberdaya dan menggunakannya secara efisien dan efektif dalam suatu aturan yang telah disepakati bersama, untuk itu perlu adanya penataan pembagian kerja, struktur pola hubungan kerja antara sekelompok orang-orang yang memegang posisi untuk bekerja sama secara teratur guna mencapai tujuan tertentu.

Menurut Louis AllenOrganisasi adalah proses mengidentifikasi dan mengelompokkan pekerjaan yang harus dilakukan, mendefinisikan dan mendelegasikan tanggung jawab dan wewenang dan membangun hubungan untuk tujuan memungkinkan orang untuk bekerja paling efektif bersama dalam mencapai tujuan.

\section{Manfaat Dari Organisasi}

Setelah mengetahui pengertian organisasi yang dipaparkan di atas, maka selanjutnya ada manfaat dari organisasi tersebut. Karena setiap hal tentu memiliki manfaat yang akan diberikan. Di mana manfaat tersebut pada dasarnya memiliki dampak yang bersifat positif sehingga tidak merugikan. Berikut ini merupakan paparan mengenai manfaat dari organisasi.

1. Meningkatkan Kemampuan Dalam Berkomunikasi

Komunikasi merupakan suatu hal yang harus dilakukan dengan cara yang sopan apalagi jika berbicara di depan umum. Maka dari itu, selain sopan juga perlu keberanian dalam menyampaikan aspirasi tersebut di depan umum. Karena memang pada dasarnya setiap masuk dalam organisasi tentu harus menyampaikan beberapa pendapat. Dari hal tersebut secara tidak langsung bisa melatih seseorang dalam berkomunikasi.

\section{Dapat Mencapai Tujuan}

Seperti yang dibahas mengenai pengertian organisasi yang 


\section{JURNAL ABDIMAS

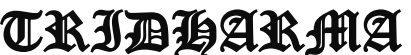 AtA}

tentunya memiliki tujuan yang akan dicapai. Sehingga manfaat dari organisasi tersebut adalah untuk mencapai tujuan dengan mudah bersama dengan para anggota. Karena setiap tujuan tentunya akan dibagi dengan anggota lainnya. Selain itu, tujuan dari organisasi tersebut juga harus memiliki susunan yang sistematis.

3. Menjadi Motivasi Dalam Membangkitkan Jiwa Pemimpin

Dalam organisasi tentu setiap anggota akan bersaing untuk menjadi seorang ketua atau pemimpin dari organisasi tersebut. Maka dari itu, organisasi bisa memberikan manfaat dalam membangkitkan jiwa pemimpin. Namun untuk menjadi pemimpin dalam sebuah organisasi harus mementingkan masalah organisasi dibandingkan dengan masalah individu.

4. Mampu Memecahkan Masalah yang Ada

Masalah dalam setiap organisasi memang biasanya terjadi dalam waktu yang tidak ditentukan. Baik masalah tersebut bersifat kecil maupun besar yang disebabkan dari berbagai hal. Seperti disebabkan karena memiliki perbedaan pendapat dari anggota. Maka dari itu, permasalahan yang timbul tersebut harus diselesaikan dengan menunjukkan sikap yang lebih kompleks dan majemuk.

5. Memperluas Wawasan yang Dimiliki

Wawasan merupakan sebuah pengetahuan yang didapatkan dari mana saja dan kapan pun. Salah satunya dengan masuk dalam sebuah organisasi untuk memperluas wawasan tersebut. Di mana wawasan ini di dapatkan dengan mengikuti seminar, diskusi, dan agenda lain yang ada di dalam organisasi. Sehingga hal tersebut bisa memberikan pengetahuan baru untuk memperluas wawasan.

6. Memperluas Pergaulan dan Mengatur Waktu

Dalam organisasi memang terbagi dari beberapa orang yang berasal dari berbagai kalangan yang berbeda. Sehingga hal tersebut menyebabkan setiap anggota organisasi bisa memperluas pergaulan yang ada. Selain itu, bisa juga melatih kedisiplinan dalam mengatur waktu yang dimiliki. Karena memang kegiatan yang dimiliki bukan hanya organisasi saja tetapi memiliki aktivitas lain.

7. Memiliki Rasa Tanggung Jawab Yang Tinggi

Manfaat lainnya adalah setiap anggota organisasi memiliki rasa tanggung jawab yang tinggi. Di mana tanggung jawab yang dimaksud adalah bertanggung jawab terhadap apa yang menjadi amanah. Seperti bertanggung jawab terhadap amanah pada saat menjabat sebagai pemimpin atau ketua dari organisasi. Sehingga seorang pemimpin ini harus melaksanakan hal tersebut dengan baik.

8. Memiliki Mental Yang Kuat Pada Saat Menghadapi Tekanan

Mental yang kuat memang harus dipersiapkan terlebih dahulu 


\section{JURNAL ABDIMAS

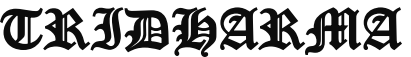 \\ AlA}

sebelum masuk atau bergabung dalam sebuah organisasi. Karena memang pada dasarnya ada tekanan yang muncul dari pihak lain untuk bersikap tegas dan tahan banting. Selain itu, anggota organisasi akan digembleng sehingga terbiasa untuk menghadapi tekanan tersebut. Oleh karena itu, kepribadian seseorang akan menjadi lebih percaya diri dan disiplin.

\section{Fungsi yang Didapatkan Dalam Berorganisasi}

Selain pengertian organisasi dan manfaat dari organisasi tersebut, ada pula fungsi organisasi yang harus diketahui. Sama halnya dengan manfaat organisasi, fungsi organisasi juga memiliki dampak yang bersifat positif bagi para pelakunya. Berikut ini merupakan paparan mengenai fungsi yang didapatkan dalam berorganisasi.

\section{Memberikan Arahan}

Dalam memberikan arahan yang dimaksud adalah organisasi bisa mengajarkan seseorang mengenai apa yang baik dan yang buruk. Dalam hal ini organisasi akan memberitahukan mengenai apa yang baik dilakukan dan apa yang buruk sehingga tidak bisa dilakukan. Selain itu, mengenai arahan tersebut adalah dapat juga dilihat dari pembagian kerja yang diberikan untuk setiap anggota.

2. Meningkatkan Skill

Selanjutnya dengan berorganisasi adalah dapat meningkatkan skill yang dimiliki oleh setiap anggota, dimana skill yang dimaksud adalah seperti untuk menjadi seorang pemimpin dan berbicara di depan umum.

Hal tersebut bisa didapatkan ketika masuk dalam sebuah organisasi, karena Anda akan memiliki motivasi untuk meningkatkan kemampuan yang dimiliki tersebut. Oleh Karena itu, cara berbicara di depan umum tidak gugup.

3. Mendapatkan Pengalaman Baru
Pengalaman yang didapatkan dari organisasi tentu saja tidak bisa didapatkan dari kegiatan lainnya. Karena kegiatan yang dilakukan dalam sebuah organisasi merupakan suatu pelajaran yang sangat berharga. Di mana pengalaman baru yang bisa di dapatkan tersebut seperti membuat laporan dari kegiatan organisasi yang telah dilakukan. Selain itu, bisa pula memiliki pengalaman saat menjadi pemimpin.

4. Mampu Artikulasi dan Agregasi

Dalam fungsi yang satu ini dijadikan sebagai instrumen yang mampu dalam artikulasi dan agregasi sebuah kepentingan umum dan individu. Untuk fungsi yang satu ini bisa didapatkan jika bergabung dengan organisasi yang berbasis internasional. Karena bisa dijadikan sebagai bentuk dari kontak institusionalisme dengan partisipan aktif. Di mana hal yang dimaksud tersebut adalah forum diskusi dan negosiasi.

5. Norma dan Rekrutmen

Fungsi organisasi selanjutnya adalah memberikan kontribusi yang memiliki arti penting untuk berbagai aktivitas yang bersifat normatif. Di mana contoh dari hal tersebut seperti penetapan nilainilai tertentu. Selain itu, organisasi juga memiliki fungsi sebagai rekrutmen atau menarik setiap anggota untuk menjadi partisipan.

\section{Metode Pelaksanaan}

Metode pelaksanaan pengabdian ini dilakukan dalam beberapa kegiatan yaitu tahap survei yaitu sosialisasi dilakukan dengan menyusun berbagai hal yang akan disampaikan pada saat kegiatan pengabdian yang akan dilakukan yang meliputi: penyusunan materi yang akan diberikan, penyusunan jadwal pemberian materi, pembagian tugas tim pengabdian dan survei ke lokasi pengabdian. Tahap sosialisasi yaitu sebelum kegiatan pengabdian dilaksanakan terlebih dahulu dilakukan tahap sosialisasi yaitu 


\section{JURNAL ABDIMAS

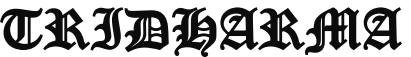 \\ AlA}

melakukan silaturahmi dengan ketua yayasan, menyampaikan maksud dan tujuan pengabdian ini. Pada tahap ini juga dilakukan jalinan kerjasama dan menentukan jadwal kegiatan pengabdian. Tim pelaksana kegiatan pengabdian pada masyarakat adalah dosen Fakultas Ekonomi jurusan manajemen sebanyak 5 orang. Tim pengabdian memberikan materi tentang penyuluhan pengembangan sumber daya manusia dengan memperkuat budaya organisasi melalui peningkatan value pada lembaga pengembangan masyarakat Kelurahan Pondok Benda Kota Tangerang Selatan

\section{HASIL DAN PEMBAHASAN}

Pengabdian Masyarakat (LPPM) Universitas Pamulang yang dilakukan oleh dosen-dosen program studi Manajemen telah berjalan dengan lancar dan mendapat sambutan hangat dari tempat pelaksanaan kegiatan ini yaitu Karang Taruna Kel. Pondok Benda Kec. Pamulang Kota Tangerang Selatan.

Harapan kami dengan pengabdian ini dapat membuka wawasan masyarakat yang diperoleh adalah bertambahnya keilmuan bagi para Karang Taruna untuk meningkatkan motivasi berorganisasi dan meningkatkan nilai Karang Taruna dalam masyarakat sekitar mempunyai dampak positif pada lingkungan masyarakat Kel. Pondok Benda khususnya dan masyarakat Kota Tangerang Selatan umumnya.

\section{KESIMPULAN DAN SARAN Kesimpulan}

Kegiatan PKM yang dilaksanakan di Kel. Pondok Benda Kota Tangerang Selatan berjalan sesuai dengan apa yang diharapkan, dimana para peserta bisa mendapatkan input dari materi-materi yang disampaikan narasumber.

\section{Saran}

1. Melihat respon dari kegiatan PKM yang dilakukan di Kel. Pondok
Benda Kota Tangerang Selatan ini, kegiatan PKM sepatutnya masih difokuskan pada Karang Taruna.

2. Kegiatan PKM pada Karang Taruna hendaknya masih difokuskan pada materi-materi yang terkait dengan manajemen, sumber daya manusia dan organisasi dengan tujuan membangun jiwa kepemimpinan dan nasionalis.

3. Kegiatan PKM dengan sasaran Karang Taruna membangun brand image Unpam selain sebagai tempat belajar juga sebagai penggerak organisasi.

\section{DAFTAR PUSTAKA}

Allen

https://projasaweb.com/pengertian-

Louis, organisasi/

Gibson, James L., 2010. Kepemimpinan Organisasi: Perilaku dan Struktur. Jakarta: Erlangga.

Hardjana, A.M. 2003. Komunikasi Intrapersonal \& Interpersonal, Jakarta. Kanisius.

Hasibuan, Malayu S. P., 2009. Manajemen Sumber Daya Manusia. Jakarta: Bumi Aksara.

Hasibuan.Malayu.SP; 2008.Organisasi dan Motivasi Jakarta: Bumi Aksara

Ishak dan Hendri Tanjung; 2010.Manajemen Motivasi. Jakarta. PT. Grasindo.Jakarta

Pasaribu, V. L. D., Susanti, F., \& Hartuti, E. T. K. (2019). Memotivasi Siswa dan Siswi SMK Letris Indonesia di Dalam Menentukan Pilihan Untuk Melanjutkan Pendidikan Atau Bekerja Setelah Lulus Sekolah. Jurnal Pengabdian Dharma Laksana, 1(2), 161-172. 


\section{JURNAL ABDIMAS

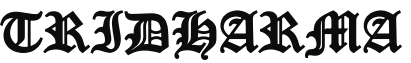

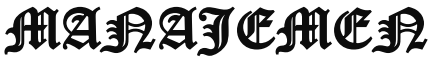

P-ISSN 2715-7105, E-ISSN 2716-070X

Jurnal ABDIMAS Vol. 2, No. 1, Januari 2021,Hal (35-43)

@ Prodi Manajemen Fakultas Ekonomi Universitas Pamulang

Email: abdimasjurnal.unpam@ gmail.com Telp: (021) 741-2566
Pasaribu, V. L. D., Agrasadya, A., Shabrina, N., \& Krisnaldy, K. (2020). MENJADI ENTERPRENEUR MUDA YANG MEMILIKI JIWA LEADERSHIP UNTUK MENGHADAPI MASA DEPAN. Abdi Laksana, 1(1).

Pasaribu, V. L. D., Elburdah, R. P., Sudarso, E., \& Fauziah, G. (2020). PENGGUNAAN MANAJEMEN WAKTU TERHADAP PENINGKATAN PRESTASI BELAJAR DI SMP ARAISIYAH. Jurnal ABDIMAS Tri Dharma Manajemen, 1(1).

Pasaribu, V. L. D., Sulaiman, S., Sutiman, S., Thaharudin, T., \& Purnomo, B. Y. (2020). PENGENALAN LETAK POSYANDU TERDEKAT DIKELURAHAN PISANGAN DENGAN MANAJEMEN PEMASARAN REVOLUSI $\quad 4.0 \quad$ UNTUK MENINGKATKAN PENGETAHUAN MASYARAKAT LETAK DAN FUNGSI POSYANDU TERDEKAT PADA KELURAHAN PISANGAN. DEDIKASI PKM, 1(1), 105-110.

Pasaribu, V. L. D., Oktrima, B., Prabowo, B., Arianto, N., \& Haryoko, U. B. (2020). PROGAM PENDAMPINGAN DAN PENYELENGGARAAN PENDIDIKAN ANAK PADA USIA DINI TERHADAP PRESTASI BELAJAR DILINGKUNGAN RT 020 RW 009. KEL GIRI PENI. KEC WATES. YOGYAKARTA. JURNAL LOKABMAS KREATIF, 1(1), 71-75.

Priono, 2007, Pengantar Manajemen, Zifatama Pubblisher, Sidoarjo https://accurate.id/marketingmanajemen/pengertian-organisasi/

\section{DOKUMENTASI FOTO KEGIATAN}
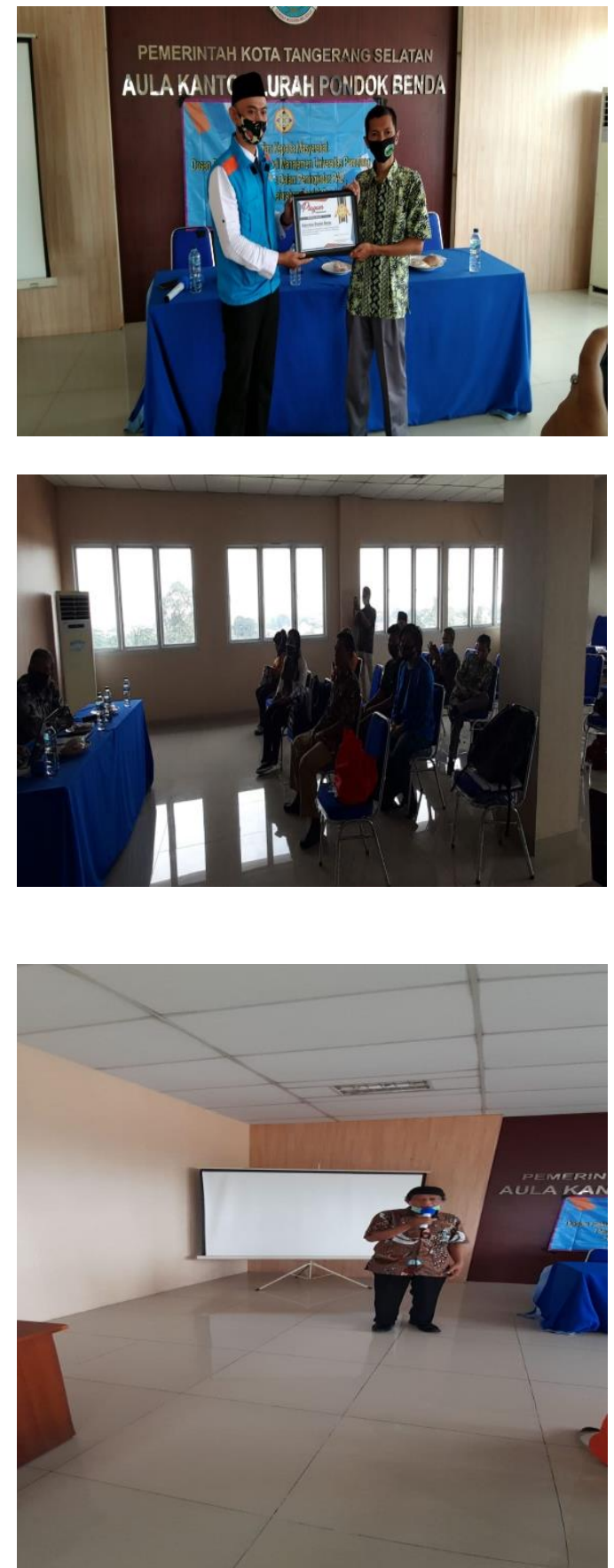
JURNAL ABDIMAS

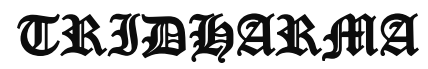

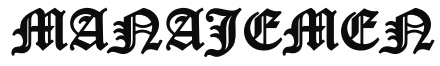

P-ISSN 2715-7105, E-ISSN 2716-070X

Jurnal ABDIMAS Vol. 2, No. 1, Januari 2021,Hal (35-43)

@Prodi Manajemen Fakultas Ekonomi Universitas Pamulang

Email: abdimasjurnal.unpam@ gmail.com Telp: (021) 741-2566 